\title{
On the question of training of future medical specialists on the basis of interdisciplinary integration
}

\author{
Kalyniuk N.* \\ I. Horbachevsky Ternopil National Medical University, Ternopil, Ukraine
}

Received: $04.06 .2020 \quad$ Accepted: 24.06 .2020

\begin{abstract}
It is substantiated that one of the effective ways to improve the quality of education is interdisciplinary integration. The interdisciplinary approach based on the new educational standards presupposes, first of all, the ability of the medical education seeker to solve problems and take responsibility; act in an unstable context; motivation of students to study a certain discipline, thorough understanding and comparison; application of the acquired knowledge in practice; broadening the horizons, increasing the independence and creativity of future medical professionals; integration of the acquired knowledge, skills and abilities into one whole and perception of the material mastered during all training as inseparable unity. Methodological aspects of training a future medical specialist in the system of higher professional education in the conditions of interdisciplinary integration are considered. The main directions of improving the professional training of medical students on the basis of integration of different approaches are identified. The importance of applying interdisciplinary integration in the training of future medical professionals on the example of a combination of clinical, bioethical and legal knowledge is substantiated. The issue of application of interdisciplinary integration in the training of medical students is covered. The factors of optimization of the process of training future medical specialists on the basis of interdisciplinary connections are considered. It is shown that the application of interdisciplinary integrative technologies provides grounds for the formation and development of future medical professionals in the field of analytical and critical thinking, which is the key to improving the quality of medical education. It is proved that the professional training of future specialists in the medical field is in dynamic development, which is due to the priority of improving the quality of medical education. It was found that the effectiveness of the integration approach in the training of future medical professionals, in order to improve the quality of their education, requires improvement of the methodological concept in the development of educational and methodological complex of professional training on the basis of interdisciplinary integration. This can be ensured by taking into account the following factors: social demands for professional activity; the specifics of training at clinical departments and the peculiarities of mastering non-core disciplines; providing scientific, informational and methodological support of the educational process; formation and development of future medical professionals of analytical and critical types of thinking. The proposed will ensure high-quality readiness of future medical professionals for their professional activities.
\end{abstract}

Key words: interdisciplinary integration, professional training, higher education, methodical concept, quality of education, medical student.

\section{До питання підготовки майбутніх медичних фахівців на засадах міждисциплінарної інтеграції}

\author{
Калинюк Н. М. \\ Тернопільський національний медичний університет імені І. Я. Горбачевського, Тернопіль, Україна
}

\begin{abstract}
Анотація. Обгрунтовано, що одним із ефективних способів підвищення якості освіти $є$ міждисциплінарна інтеграція. Міждисциплінарний підхід в основі нових стандартів освіти передбачає, передусім, здатність здобувача медичної освіти вирішувати проблеми та брати на себе відповідальність; діяти в нестабільному контексті; мотивацію студентів до вивчення певної дисципліни, ірунтовного осмислення та порівняння; застосування отриманих знань на практиці; розширення кругозору, підвищення самостійності та творчості майбутніх фахівців медичної галузі; інтеграцію набутих знань, навичок та вмінь в одне ціле та сприйняттю
\end{abstract}

\footnotetext{
Corresponding Author: Kalyniuk Natalia Mykolayvna, Tel. +380976539021 .E-mail: kalunyknm@tdmu.edu.ua I. Horbachevsky Ternopil National Medical University, sit. M. Voli, 1, Ternopil, Ukraine.

Відповідальний автор: Калинюк Наталя Миколаївна, Тел. +380976539021 .E-mail: kalunyknm@tdmu.edu.ua Тернопільського національного медичного університету імені І.Я. Горбачевського. Майдан Волі, 1, м. Тернопіль, Україна, 46016.
} 
засвоєного протягом усього навчання матеріалу як нерозривної єдності. Розглянуто методичні аспекти підготовки майбутнього медичного фахівця у системі вищої професійної освіти в умовах міждисциплінарної інтеграції. Визначено основні напрями вдосконалення професійної підготовки студентів-медиків на засадах інтеграції різних підходів. Обґрунтовано важливість застосування міждисциплінарної інтеграції при підготовці майбутніх фахівців медичної галузі на прикладі поєднання клінічних, біоетичних та правових знань. Висвітлено питання застосування міждисциплінарної інтеграції у ході підготовки студентів-медиків. Розглянуто чинники оптимізації процесу підготовки майбутніх фахівців-медиків на основі міжпредметних зв'язків. Показано, що застосування міждисциплінарних інтегративних технологій дає підстави для формування та розвитку у майбутніх фахівців медичної галузі аналітичного та критичного мислення, що є запорукою підвищення рівня якості медичної освіти. Доведено, що професійна підготовка майбутніх фрахівців медичної галузі перебуває у динамічному розвитку, що зумовлено пріоритетністю підвищення рівня якості медичної освіти. З'ясовано, що результативність інтеграційного підходу в ході підготовки майбутніх фахівців медичної галузі, з метою підвищення рівня якості їх освіти, витребовує вдосконалення методичного концепту при розробці навчально-методичного комплексу професійної підготовки фахівців на засадах міждисциплінарної інтеграції. Це можливо забезпечити, враховуючи наступні чинники: соціальні запити до професійної діяльності; специфіку навчання на клінічних кафедрах та особливості засвоєння непрофільних дисциплін; забезпечення наукового, інформаційного та методичного супроводу навчального процесу; формування i розвиток у майбутніх фрахівців медичної галузі аналітичного й критичного типів мислення. Пропоноване забезпечить якісну готовність майбутніх фахівців медичної галузі до їх професійної діяльності.

Ключові слова: міждисциплінарна інтеграція, професійна підготовка, вища освіта, методичний концепт, якість освіти, студент - медик.

\title{
К вопросу подготовки будущих медицинских специалистов на принципах междисциплинарной интеграции
}

\author{
Калинюк Н. М. \\ Тернопольский национальный медицинский университет имени И. Я. Горбачевского., Тернополь, Украина
}

\begin{abstract}
Аннотация. Обосновано, что одним из эффективных способов повышения качества образования является междисциплинарная интеграция. Междисциплинарный подход в основе новых стандартов образования предусматривает, прежде всего, способность соискателя медицинского образования решать проблемы и брать на себя ответственность; действовать в нестабильной контексте; мотивацию студентов к изучению определенной дисциплины, основательного осмысления и сравнения; применение полученных знаний на практике; расширение кругозора, повышение самостоятельности и творчества будущих специалистов медицинской отрасли; интеграцию приобретенных знаний, навыков и умений в одно целое и восприятию усвоенного в течение всего обучения материала как неразрывного единства. Рассмотрены методические аспекты подготовки будущего медицинского специалиста в системе высшего профессионального образования в условиях междисциплинарной интеграции. Определены основные направления совершенствования профессиональной подготовки студентов-медиков на основе интеграции различных подходов. Обоснована важность применения междисциплинарной интеграции при подготовке будущих специалистов медицинской отрасли на примере сочетание клинических, биоэтических и правовых знаний. Освещены вопросы применения междисциплинарной интеграции в ходе подготовки студентов-медиков. Рассмотрены факторы оптимизации процесса подготовки будущих специалистов-медиков на основе межпредметных связей. Показано, что применение междисциплинарных интеграционных технологий дает основания для формирования и развития у будущих специалистов медицинской отрасли аналитического и критического мышления, что является залогом повышения уровня качества медицинского образования. Доказано, что профессиональная подготовка будущих специалистов медицинской отрасли находится в динамичном развитии, что обусловлено приоритетностью повышение уровня качества медицинского образования. Установлено, что результативность интеграционного подхода в ходе подготовки будущих специалистов медицинской отрасли, с целью повышения уровня качества их образования, истребует совершенствования методического концепта при разработке учебно-методического комплекса профессиональной подготовки специалистов на основе междисциплинарной интеграции. Это возможно обеспечить, учитывая следующие факторы: социальные запросы к профессиональной деятельности; специфику обучения на клинических кафедрах и особенности усвоения непрофильных дисциплин; обеспечение научного, информационного и методического сопровождения учебного процесса; формирование и развитие у будущих специалистов медицинской отрасли аналитического и критического типов мышления. Предлагаемое обеспечит качественную готовность будущих специалистов медицинской отрасли к их профессиональной деятельности..
\end{abstract}

Ключевые слова: междисциплинарная интеграция, профессиональная подготовка, высшее образование, методический концепт, качество образования, студент - медик. 


\section{Bcmyn}

У сучасному суспільстві, що розвивається в умовах глобалізації, використання інформаційних технологій, пріоритетним напрямом в освіті $€$ її якість. Цей критерій $є$ одним з основних орієнтирів при визначенні авторитетності та конкурентноспроможності вищих закладів освіти. Це ж стосується проблематики ефективності сучасної системи підготовки майбутніх медичних фрахівців.

Питання щодо аналізу тих чи інших педагогічних явищ і процесів, що забезпечують якість освіти досліджували у своїх наукових працях такі вчені як А. Вихрущ [1. с. 57], Н. Волощук [2, с. 8], Н. Єлагіна [3, с. 48], Н. Калинюк [4, с. 254], В. Кульчицький [5, с. 89], І. Мельничук [6, с. 97], Я. Нахаєва [7, с. 296$], 0$. Пилипишин [8, с. 186], І. Рогальський [9, с. 48], Л. Романишина [10], Т. Федірчик [11], Н. Федчишин [12, с. 120] , О. Христенко [13, с. 16], М. Чорненький [14, с. 27], А. Шульгай [15, с. 113] та ін. Разом з тим, достатньо великий обсяг проведених ними досліджень вказує на необхідність підвищення якості освіти в цілому, і в медичній освіті зокрема.

Якісна освіта сьогодні - передусім та, яка відповідає вимогам інформаційного суспільства та формує у здобувача ті компетентності, що найбільш затребувані на сучасному мінливому ринку праці. В межах реалізації вимог Болонського процесу на теренах України якість освіти слід розглядати як юридичну гарантію права особи на освіту, що характеризується сукупністю певних властивостей освітніх послуг, які зумовлюють її придатність задовольняти певні потреби відповідно до свого призначення та відповідати ознакам особливості, надійності, довговічності, рівню визначеної стандартизації і уніфікації.

Одним із есрективних способів підвищення якості освіти $€$ міждисциплінарна інтеграція. Міждисциплінарний підхід в основі нових стандартів освіти передбачає, передусім, здатність здобувача медичної освіти вирішувати проблеми та брати на себе відповідальність; діяти в нестабільному контексті; мотивацію студентів до вивчення певної дисципліни, ґрунтовного осмислення та порівняння; застосування отриманих знань на практиці; розширення кругозору, підвищення самостійності та творчості майбутніх фрахівців медичної галузі; інтеграцію набутих знань, навичок та вмінь в одне ціле та сприйняттю засвоєного протягом усього навчання матеріалу як нерозривної єдності. Звідси і бере свій початок потреба у нових дескрипторах Національної рамки кваліфікацій відповідно до Рамки кваліфікацій Європейського простору вищої освіти за категоріями: автономність і відповідальність, знання, комунікація, інтеграція, уміння.

Mema cmammi: обґрунтувати важливість застосування міждисциплінарної інтеграції при підготовці майбутніх фахівців медичної галузі на прикладі поєднання клінічних, біоетичних та правових знань. Висвітлити питання застосування міждисциплінарної інтеграції у ході підготовки студентів-медиків. Розглянути чинники оптимізації процесу підготовки майбутніх фахівців-медиків на основі міжпредметних зв'язків. Показано, що застосування міждисциплінарних інтегративних технологій дає підстави для формування та розвитку у майбутніх фахівців медичної галузі аналітичного мислення.

\section{II Матеріали і методи дослідження}

Для реалізації поставленої мети застосовано такий комплекс методів: теоретичного аналізу, порівняння, обґрунтування, узагальнення, систематизації теоретичного та практичного матеріалу, вивчення основних міжнародних та національних нормативно-правових актів у контексті характеристики клятви лікаря під час підготовки майбутніх фахівців медичної галузі на засадах міждисциплінарної інтеграції; формулювання і систематизації висновків.

Реформування системи охорони здоров'я зумовлює нові вимоги у у системі вищої медичної освіти та формуванні майбутніх фахівців нового типу, що повинні досконало володіти спеціальністю, мати навики комунікабельності, ділового спілкування, вміти адаптуватися до вимог сьогодення, орієнтуватися у дотриманні прав людини у сфрері охорони здоров'я під час виконання своїх професійних обов'язків.

Означена проблематика охоплюється необхідністю впровадження для студентів вищих медичних закладів освіти дисципліни «Медичне право України», а також курсів за вибором таких як «Правові аспекти окремих видів медичної діяльності», «Права людини у сфері охорони здоров'я», «Правове забезпечення сфери охорони здоров'я» та ін. I це пояснюється тим, що саме інтегративний підхід у 
професійній медичній освіті становить $є$ методологічною основою міждисциплінарної інтеграції. При чому, під міждисциплінарною інтеграцією слід розуміти саме процес узгодження змісту навчальних дисциплін щодо відображення ними єдиних, безперервних і ціннісних явищ професійної діяльності.

У ході підготовки майбутніх фрахівців медичної галузі у закладах вищої освіти простежується застосування інтегративного підходу в навчальному процесі, що полягає у логічній послідовності введення навчальних дисциплін. Основним ж завданням міждисциплінарної інтеграції $є$ методичне опрацювання змісту навчальних дисциплін, що полягає в систематизації та узагальнені матеріалу, одержаного при їх вивченні. Застосування інтегрального підходу при підготовці майбутніх фахівців медичної галузі слід навести на прикладі характеристики Клятви лікаря України, що вивчається студентами під час засвоєння низки дисциплін, а саме «Вступ до спеціальності», «Біоетика», «Соціальна медицина», «Медичне право України» і застосовуватиметься у професійній діяльності в майбутньому. I це з тих причин, що сучасний розвиток технологій, наукових знань і практика їх впровадження та застосування у сфері охорони здоров'я зумовлює правові, соціальні та моральноетичні проблеми. Першоджерелом для національного законодавства завжди $є$ міжнародно-правові стандарти у сфері біомедицини. Адже захист і дотримання основних прав і свобод людини це не компетенція лише окремої країни, а найважливіше завдання усього міжнародного співтовариства. Міжнародні стандарти у ссрері біомедицини є загальновизнаними міжнародно-правовими нормами, що закріплюють на загальнолюдському рівні статус особистості і встановлюють перелік основних прав і свобод у сфері медицини і біології, обов'язок держави їх дотримуватися, а також межі можливого або примусового їх обмеження.

Розкриваючи проблематику міжнародно-правових стандартів у сфері біомедицини, слід визнати виняткове значення участі лікарів у цих правовідносинах. Основоположними міжнародними документами, що становлять базис для будь-якої професійної діяльності лікаря $є$ Міжнародна клятва лікаря (1958р.) та Міжнародний кодекс медичної етики (1949р.). Це зумовлене тим, що після здобуття рівня вищої освіти за спеціальністю «Медицина» на кожного випускника покладається обов'язок скласти клятву лікаря. В Україні Клятва лікаря України затверджена підзаконним нормативно-правовим актом Указом Президента України від 15.06.1992р., що був розроблений відповідно до міжнародних стандартів у сфері біоетики.

Професія лікаря завжди витребовує підвищений рівень гуманізму та моральних принципів у людей, що обирають цю діяльність. Біоетика тісно пов'язана з законом.

Усталені тисячоліттями моральні норми професійної поведінки лікарів знайшли своє відображення у законодавчих приписах. Універсальність цієї професії зумовило затвердження біоетичних принципів на міжнародному рівні, що становить основу для однакового розуміння сутності клятви лікаря у різних країнах. Офіційність та урочистість процедури прийняття клятви лікаря породжує повагу, вірність, гордість, доброчесність і сумлінність у майбутній професійній діяльності лікарів.

Процедура прийняття клятви лікаря України відповідає вимогам міжнародних стандартів біоетики. А саме: клятву лікаря повинні давати усі випускники медичних закладів вищої освіти; в урочистій обстановці в присутності їх професорсько-викладацького складу і представників громадськості. Текст клятви лікаря проголошується колективно і підписується випускником та зберігається у його особовій справі. При цьому, в дипломі робиться відмітка про прийняття Клятви лікаря, текст якої вкладається в диплом. Ці норми Клятви лікаря України узгоджуються із міжнародними принципами біоетики 3 наступними приписами: «з повагою та вдячністю відноситися до своїх вчителів» (Жеревська декларація, 1948 р.); «лікар повинен вести себе по відношенню до своїх колег так, як хотів би, щоб вони вели себе по відношенню до нього»; «лікар не повинен переманювати пацієнтів у своїх колег» (Міжнародний кодекс медичної етики, 1949 р.).

\section{III Результати}

Принципи Женевської декларації та Міжнародного кодексу медичної етики закладають обов'язки лікарів, зумовлені біоетичними засадами, які трансформовані у Клятву лікаря України.

Порівняльну характеристику спробуємо зобразити у таблиці 1. 
Табл. 1. Порівняльна характеристика Клятви лікаря України з міжнародно-правовими стандартами у сфері біоетики

\begin{tabular}{|c|c|c|c|}
\hline Обов’язок лікаря & $\begin{array}{c}\text { Клятва лікаря } \\
\text { України (1992р.) }\end{array}$ & $\begin{array}{c}\text { Міжнародний кодекс } \\
\text { медичної етики (1949р.) }\end{array}$ & $\begin{array}{c}\text { Міжнародна клятва } \\
\text { лікаря (1948р.) }\end{array}$ \\
\hline $\begin{array}{l}\text { Обов'язок подавати } \\
\text { своєчасну та } \\
\text { кваліфріковану медичну } \\
\text { і лікарську допомогу, } \\
\text { сприяти охороні і } \\
\text { зміцненню здоров'я } \\
\text { людей, запобіганню і } \\
\text { лікуванню } \\
\text { захворювань }\end{array}$ & $\begin{array}{l}\text { «всі знання і сили } \\
\text { віддати охороні й } \\
\text { поліпшенню здоров'я } \\
\text { людини, лікуванню і } \\
\text { запобіганню } \\
\text { захворювань...»; } \\
\text { «бути завжди готовим } \\
\text { надавати медичну } \\
\text { допомогу ...» }\end{array}$ & $\begin{array}{l}\text { «... самовіддано надавати } \\
\text { компетентну медичну допомогу з } \\
\text { повною технічною і моральною } \\
\text { незалежністю, зі співчуттям та з } \\
\text { повагою до людської гідності»; } \\
\text { «лікар завжди повинен пам'ятати про } \\
\text { обов'язок збереження людського } \\
\text { життя»; } \\
\text { «надавати невідкладну допомогу як } \\
\text { виконання гуманітарного обов'язку, } \\
\text { якщо немє впевненності в тому, що } \\
\text { інші хочуть і можуть надати цюо } \\
\text { допомогу» }\end{array}$ & $\begin{array}{l}\text { «турбуватися, насамперед, } \\
\text { про здоров'я пацієнта»; } \\
\text { «не дозволяти обставинам, } \\
\text { пов'язаним з віком, станом } \\
\text { здоров'я, віросповіданням, } \\
\text { расовою приналежністю, } \\
\text { статтю, національністю, } \\
\text { політичними переконаннями, } \\
\text { суксуальною орієнтацією чи } \\
\text { соціальним станом, } \\
\text { перешкоджати виконанню } \\
\text { мого обов'язку перед } \\
\text { пацієнтом» }\end{array}$ \\
\hline $\begin{array}{l}\text { Обов'язок } \\
\text { дотримуватися вимог } \\
\text { професійної етики і } \\
\text { деонтології, зберігати } \\
\text { лікарську таємницю }\end{array}$ & $\begin{array}{l}\text { «... сумлінно працювати } \\
\text { там, де цього } \\
\text { вимагають інтереси } \\
\text { суспільства»; } \\
\text { «...уважно і дбайливо } \\
\text { ставитися до хворого, } \\
\text { зберігати лікарську } \\
\text { таємницю» }\end{array}$ & $\begin{array}{l}\text { «лікар повинен завжди підтримувати } \\
\text { найвищі стандарти професіійної } \\
\text { діяльності»; } \\
\text { «лікар повинен бути чесний з } \\
\text { пацієнтами, повинен боротися з } \\
\text { просессійними і особистісними } \\
\text { недоліками інших лікарів, повинен } \\
\text { викривати обман та шахрайство»; } \\
\text { «Лікар повинен поважати права } \\
\text { пацієнта, колег, іншого медичного } \\
\text { персоналу, і повинен дотримуватися } \\
\text { конффіденційності по відношенню до } \\
\text { пацієнта»; } \\
\text { Лікар повинен тримати в абсолютній } \\
\text { таємниці все, що він знає про свого } \\
\text { пацієнта, навіть після смерті } \\
\text { останнього» }\end{array}$ & $\begin{array}{l}\text { «присвятити своє життя для } \\
\text { блага людини»; } \\
\text { Зберігати довірені мені } \\
\text { таємниці, навіть після смерті } \\
\text { пацієнта. }\end{array}$ \\
\hline $\begin{array}{l}\text { Обов'язок поширювати } \\
\text { наукові та медичні } \\
\text { знання серед } \\
\text { населення }\end{array}$ & $\begin{array}{l}\text { «веертатися, коли цього } \\
\text { вимагають інтереси } \\
\text { хворого, за порадою до } \\
\text { товаришів по професії і } \\
\text { самому ніколи не } \\
\text { відмовляти їм у пораді } \\
\text { та допомозі»; } \\
\text { «берегти і розвивати } \\
\text { благородні традиції } \\
\text { вітчизняної медицини» }\end{array}$ & $\begin{array}{l}\text { «Лікар повинен надавати пацієнту усі } \\
\text { ресурси своєї науки. Якщо лікар не } \\
\text { має можливості провести діагностику } \\
\text { або лікування, він повинен залучити } \\
\text { іншого лікаря, у якого є такі } \\
\text { можливості»; } \\
\text { «Лікар повинен бути значно } \\
\text { обережним, розповсюджуючи } \\
\text { відкриття, нові технології, або інші } \\
\text { лікувальні методики, по } \\
\text { непрофесійними джерелам } \\
\text { інфрормації» }\end{array}$ & $\begin{array}{l}\text { «всіма доступними мені } \\
\text { засобами утверджувати } \\
\text { чесні і благородні традиції } \\
\text { професії лікаря»; } \\
\text { «не дивлячись ні на що, } \\
\text { утверджувати людське життя } \\
\text { з самого його початку як } \\
\text { найвищу цінність, і не } \\
\text { використовувати свої знання } \\
\text { лікаря всупереч законам } \\
\text { гуманності» }\end{array}$ \\
\hline $\begin{array}{l}\text { Обов'язок постійно } \\
\text { підвищувати рівень } \\
\text { профресійних знань і } \\
\text { майстерності }\end{array}$ & $\begin{array}{l}\text { «Постійно } \\
\text { вдосконалювати свої } \\
\text { медичні знання і } \\
\text { лікарську майстерність, } \\
\text { сприяти своєю працеюю } \\
\text { розвитку медичної } \\
\text { науки і практики» }\end{array}$ & $\begin{array}{l}\text { «Лікар повинен завжди виконувати } \\
\text { найвищі стандарти профресійної } \\
\text { діяльності» }\end{array}$ & $\begin{array}{l}\text { «присвятити своє життя } \\
\text { служінню для блага } \\
\text { людства» }\end{array}$ \\
\hline
\end{tabular}

Наведена порівняльна характеристика дає підстави стверджувати, що Клятва лікаря країни повністю відповідає міжнародно-правовим стандартам у сфері біоетики, зокрема Міжнародній клятві лікаря (1948р.) та Міжнародному кодексу медичної етики (1949р.). 


\section{IV Обговорення}

Застосовуючи міждисциплінарний інтегративний підхід при підготовці майбутніх фрахівців медичної галузі, з наведеного прикладу стає зрозумілим те, що різнобічний підхід, застосування методу порівняльного аналізу, розвиток творчого й логічного мислення, інтеграції одержаних знань, навичок і вмінь в одне ціле, підвищує самостійність майбутніх фрахівців медичної галузі, дає підстави для подальшого розвитку у них аналітичного і критичного типів мислення, що безпосередньо впливає на підвищення якості освіти. Підтвердження висловленої позиції знаходимо й у працях науковців, що стверджують про необхідність розробки правових актів для забезпечення належної якості надання освітніх послуг в підготовці фахівців медичної галузі, з обов'язковим попереднім обговоренням на засадах соціального діалогу із застосуванням міжнародної практики та з метою уникнення протиріч та прогалин у процесі реалізації конституційно-правових гарантій права особи на освіту з врахуванням усіх вимог Болонського процесу [16, с. 166; 17, с. 922; 18, с. 129; 19, с. 239; 20, с. 26; 21, с. 14; 22, с. 844]. Під аналітичним мисленням слід розуміти обов'язковий характер ситуації з ретельним обмірковуванням усіх позитивних моментів та їх противаг, що зумовить прийняття незалежного рішення чи видачі якого результату в майбутньому. Таким чином, у наведеному прикладі простежується формування у студентів аналітичного типу мислення. Що ж до розвитку критичного мислення, то воно матиме своє логічне продовження у подальших розмірковуванням майбутніх фахівців медичної галузі [23, с. 4; 24; 25, с. 232].

Оскільки, хоча й аналізовані три документи за своїм змістом є подібними та встановлюють загальні моральні та деонтологічні засади у професії лікаря, однак, при досить уважному порівнянні можливо зробити висновок про те, що вказані джерела по-різному розставляють акценти та пріоритети та мають деякі відмінності, що проявляється у наступному:

1. Перше що на себе звертає увагу, це те що Клятва лікаря України у першому ж пункті встановлює домінацію інтересів суспільства та держави, ніж особи («сумлінно працювати там, де цього вимагають інтереси суспільства») та наступним встановлює відповідальність лікаря не перед пацієнтом, а перед Народом і Державою. Натомість, Міжнародна клятва лікаря застосовує достатньо коротке та всеохоплююче визначення, яке не дає можливості зробити висновок про превалювання інтересів суспільства чи держави - «присвятити своє життя службі на благо людини». Цей документ також прямо заявляє про домінацію принципу гуманності - незважаючи ні на що, затверджувати людське життя 3 самого його початку як найвищу цінність й не використовувати свої знання лікаря всупереч законам гуманності;

2. На відміну від Клятви лікаря України, Міжнародна клятва лікаря та Міжнародний кодекс медичної етики встановлюють для лікаря прямий обов'язок зберігати лікарську таємницю навіть після смерті;

3. Клятва лікаря України містить в собі положення про обов'язок лікаря вдосконалювати свої знання та майстерність, розвивати науку і практику, берегти і розвивати традиції вітчизняної медицини. Міжнародна клятва лікаря таких положень не містить, натомість встановлює для лікаря обов'язок затверджувати чесні та благородні традиції професії лікаря, тобто традиції профресії в цілому (як надбання людства), а не тільки вітчизняні;

4. Міжнародний кодекс медичної етики більше уваги приділяє практичним аспектам діяльності лікарів при провадженні професійної діяльності. Зокрема, закріплює положення щодо заборони самореклами та отримання винагороди за видачу направлень та рекомендацій, недопущення впливу фінансових інтересів на провадження професійної діяльності;

5. Клятва лікаря України встановлює обов'язок для лікаря звертатися, коли цього вимагають інтереси хворого, за порадою до товаришів по професії і самому ніколи не відмовляти їм у пораді та допомозі. Дещо подібне визначення використовує і Міжнародний кодекс медичної етики: «лікар повинен надавати пацієнту всі ресурси своєї науки, а якщо не має можливості провести обстеження або лікування, то він повинен залучити іншого лікаря, у якого такі можливості є». Разом з тим, Міжнародна клятва лікаря такої деталізації питання професійних взаємовідносин та взаємодії у лікарському співтоваристві не дотримується, використовуючи більш загальне визначення обов'язку лише щодо взаємодії із колегами - «ставитися як до братів та сестер». Міжнародний кодекс медичної етики так описує окремі аспекти взаємодії у лікарському співтоваристві: лікар повинен вести себе по відношенню 
до своїх колег так, як він хотів би, щоб вони вели себе по відношенню до нього і не повинен переманювати пацієнтів у своїх колег;

6. Міжнародна клятва лікаря на відміну від Клятви лікаря України та Міжнародного кодексу медичної етики містить положення про обов'язок лікаря з повагою та подякою ставитися до своїх вчителів;

7. Клятва лікаря України прямо встановлює деонтологічно-моральний обов'язок лікаря у сфері публічного та приватного життя: «способом свого життя (своїм прикладом) підтверджувати поради, які він буде давати іншим». Міжнародні ж документи аналогічного за змістом положення не містять.

Підсумовуючи всі ці висловлені міркування, що одержані в результаті застосування міждисциплінарного інтегративного підходу, на основі поєднання аналітичного й критичного мислення, майбутній фрахівець медичної галузі підготовлений для фрормування кінцевого висновку про те, що хоча ці три документи і складають етичну базу, втім, вони дещо по-різному підходять до одного і того ж самого питання; містять певні істотні відмінності, які мають обов'язково враховуватись у кожному окремому випадку при вирішенні питання щодо того, чи порушував лікар ті чи інші етичні приписи при провадженні своєї профресійної діяльності.

\section{V Висновки}

Профресійна підготовка майбутніх фахівців медичної галузі перебуває у динамічному розвитку. Це зумовлено пріоритетністю підвищення рівня якості медичної освіти. Одним з основних напрямків вдосконалення вищої медичної освіти $€$ саме активне впровадження в навчальний процес міждисциплінарного інтегративного підходу, що повинно бути основоположним підґрунтям методичного концепту. Результативність інтеграційного підходу в ході підготовки майбутніх фахівців медичної галузі, з метою підвищення рівня якості їх освіти, витребовує вдосконалення методичного концепту при розробці навчально-методичного комплексу професійної підготовки фахівців на засадах міждисциплінарної інтеграції. Це можливо забезпечити, враховуючи наступні чинники: соціальні запити до професійної діяльності; специфріку навчання на клінічних кафедрах та особливості засвоєння непрофільних дисциплін; забезпечення наукового, інформаційного та методичного супроводу навчального процесу; формування і розвиток у майбутніх фахівців медичної галузі аналітичного й критичного типів мислення. Пропоноване забезпечить якісну готовність майбутніх фахівців медичної галузі до їх професійної діяльності.

\section{Бібліографічні посилання:}

1. Волощук Н. І., Пашинська О. С., Іваниця А. О., Таран І. В. Міждисциплінарна інтеграція як фактор удосконалення викладання фрармакології у виші. Медична освіта. Т., 2016. Вип. 4. С. 8-11.

2. Калинюк Н. М. Імплементація міжнародних та європейських освітніх стандартів у систему реалізації державної освітньої політики: гармонізація освітнього простору у формуванні професійної компетентності майбутніх фахівців. Вісник Національної академії Державної прикордонної служби України. № 3 (14). 2018. С. 243-256.

3. Кульчицький В. Патріотичне виховання як складова професійної підготовки майбутнього фахівця. Науковий вісник Ужгородського національного університету: Серія «Педагогіка. Соціальна робота». 2019. № 1 (44). С. 88-92.

4. Мельничук І. М., Ястремська С. О. Переваги самоосвітньої діяльності майбутніх магістрів медсестринства в умовах дистанційного навчання. Медична освіта. 2019. № 1. С. 96-101.

5. Нахаєва Я. М. Мельничук І. М. Формування термінологічної компетентності майбутніх фахівців як педагогічна проблема. Збірник наукових праць Національної академії Державної прикордонної служби України. Серія: Педагогічні науки. 2018. № 2 (13). С. 292-302.

6. Пилипишин О. І. Соціальні, економічні, історичні та політичні тенденції, які впливаю на роль навчання медичних сестер. Педагогіка формування творчої особистості у вищих і загальноосвітніх школах. № 69. Запоріжжя. 2020. С. 171-188.

7. Рогальський І. О., Калинюк Н. М. Особливості викладання медичного права для студентів-медиків. Медична освіта. № 1. 2018. C. $46-49$

8. Романишина Л. М., Мельничук І. М. Підготовка майбутніх фрахівців медицини до маркетингової діяльності як педагогічна проблема. Вісник Національної академії Державної прикордонної служби України. Серія: педагогіка (електронне видання). 2018. №2. URL: http://nbuv.gov.ua/UJRN/Vnadped_2018_2_14 (дата звернення 10.05.2020).

9. Мельничук І. М. Федірчик Т. Д., Калинюк Н. М. Сутність освіти як соціальної цінності. Вісник Національної академії Державної прикордонної служби України. Серія: Педагогіка. 2019. Вип. 1. URL: http://nbuv.gov.ua/UJRN/Vnadped_2019_1 7.1 (дата звернення 10.05.2020). 
10. Федчишин Н. О. Іншомовна граматична компетентність як складова підготовки майбутнього лікаря у контексті віртуально-навчального середовища. Медична освіта, 2019. № 2 (82). С. 114-121.

11. Христенко О. М. Використання ґендерно збалансованого матеріалу під час викладання історії України. Збірник наукових праць Уманського державного педагогічного університету імені Павла Тичини. 2015. № 2. С. 379-387.

12. Калинюк Н. М., Рогальський І. О., Чорненький М. В. Педагогічні (методичні) засади викладання курсу «Медичне правознавство» для студентів медичного факультету. Медична освіта. № 4. 2015. С. 27-29.

13. Шульгай А. Г., Федонюк Л. Я., Мудра А. Є., Олещук О. М. Міждисциплінарна інтеграція як складова проблемноорієнтованого навчання у медичному університеті. Медична освіта. 2018. № 4 (80). C. 113-116.

14. Kofoed M. S. To apply or not to apply: FAFSA completion and financial aid gaps. Research in Higher Education. 2017, Iss. 58(1). PP. 1-39.

15. Melnychuk I., Kalyniuk N., Humenna N., Rohalskyi I., Yastremska S., Straznikova I., Bloshchynskyi I. Organization of distance learningon "Nursing" specialty: methodological and legal aspects. International Journal of Applied Exercise Physiology. 2019: Vol. 8. N. 3.1.

16. Melnychuk I., Mozolev O., Bloshchynskyi I., Alieksieiev O., Romanyshyna L., Zdanevych L., Prontenko K., Prontenko V. Influence of modern fitness technologies on the state of health and development of motorabilities of 17-19-year-old female students. Journal of Physical Education and Sport. Physical Therapy. Sports Therapy and Reabilitation and Sport巴 (JPES), Vol 19 (Supplementis sue 3), Art 132, pp. 917-924, 2019.

17. Melnychuk I., Svyd I., Obod A., Zavolodko G., Wójcik W., Orazalieva S., Ziyatbekova G. Assessment of information support quality by "friend or foe" identification systems. Przegląde lektrotechniczny. R. 95 NR 4/2019. pp. 127-131. doi:10.15199/48. 2019.04.22.

18. Mykytenko Pavlo V., Lapinskij Vitalii V. Design of medical informatics interdisciplinary integration. Information Technologies and Learning Tools. Vol. 75. No 1. 2020. P. 26-41.

19. Okamura K. Interdisciplinarity revisited: evidence for research impact and dynamism. Palgrave Commun. 2019. Iss. 5(141). URL: https://doi.org/10.1057/s41599-019-0352-4 (дата звернення 10.05.2020).

20. Renate G. Klaassen. Interdisciplinary education: a case study. European Journal of Engineering Education. 2018. 43:6. PP. 842-859. DOI: 10.1080/03043797.2018.1442417 (дата звернення 10.05.2020).

21. Sergeeva S. Monitoring of Educational Programs for the Development of Professional Competencies by Procurement Specialists in Procurement Statistics. Academic Journal of Interdisciplinary Studies. 2019. Vol. 8. Issue 2. PP. $226-239$.

22. Viktorova Lesya V. Educational conditions for implementation of adults' distance Learning of Foreing Lanquages. Information Technologies and Learning Tools. 2020. Vol. 75. No 1. PP. 13-25.

23. Vykhrushch A., Melnychuk I., Fedchyshyn N., Pylypyshyn O. Philosophical and Cultural Aspects of Medical Profession: Philosophical and Conceptual Peculiarities. Cultura. International Journal of Philosophy of Culture and Axiology. 2019. №16 (1). P. 165-174.

24. Vykhrushch A. Poezja w procesie rozwoju twórczych zdolności studentów. Kwartalnik Edukacyjny. 2017. № 1 (88). P. 56-61.

25. Yelahina N. Fedchyshyn N., Klishch H., Horpinich T. Effective Methods in Foreign Language Teaching of Medical Students. Медична освіта. 2019. № 1 (81). С. 48-54.

\section{References:}

1. Voloshchuk, N.I., Pashyns'ka, O.S., Ivanytsya, A.O., Taran, I.V. (2016). Mizhdystsyplinarna intehratsiya yak faktor udoskonalennya vykladannya farmakolohiyi u vyshi. Medychna osvita, 4, 8-11. [in Ukrainian]

2. Kalynyuk, N.M. (2018). Implementatsiya mizhnarodnykh ta yevropeys'kykh osvitnikh standartiv u systemu realizatsiyi derzhavnoyi osvitn'oyi polityky: harmonizatsiya osvitn'oho prostoru u formuvanni profesiynoyi kompetentnosti maybutnikh fakhivtsiv. Visnyk Natsional'noyi akademiyi Derzhavnoyi prykordonnoyi sluzhby Ukrayiny, 3(14), 243-256. [in Ukrainian]

3. Kul'chyts'kyy, V. (2019). Patriotychne vykhovannya yak skladova profesiynoyi pidhotovky maybutn'oho fakhivtsya. Naukovyy visnyk Uzhhorods'koho natsional'noho universytetu: Seriya «Pedahohika. Sotsial'na robota», 1(44), 88-92. [in Ukrainian]

4. Mel'nychuk, I.M., Yastrems'ka, S.O. (2019). Perevahy samoosvitn'oyi diyal'nosti maybutnikh mahistriv medsestrynstva v umovakh dystantsiynoho navchannya. Medychna osvita, 1, 96-101. [in Ukrainian]

5. Nakhayeva, Ya.M., Mel'nychuk, I.M. (2018). Formuvannya terminolohichnoyi kompetentnosti maybutnikh fakhivtsiv yak pedahohichna problema. Zbirnyk naukovykh prats' Natsional'noyi akademiyi Derzhavnoyi prykordonnoyi sluzhby Ukrayiny. Seriya: Pedahohichni nauky, 2(13), 292-302. [in Ukrainian]

6. Pylypyshyn, O.I. (2020). Sotsial'ni, ekonomichni, istorychni ta politychni tendentsiyi, yaki vplyvayu na rol' navchannya medychnykh sester. Pedahohika formuvannya tvorchoyi osobystosti u vyshchikh i zahal'noosvtinikh shkolakh, 69, 171-188. [in Ukrainian]

7. Rohal's'kyy, I.O., Kalynyuk, N.M. (2018). Osoblyvosti vykladannya medychnoho prava dlya studentiv-medykiv. Medychna osvita, 1, 46-49. [in Ukrainian]

8. Romanyshyna, L.M., Mel'nychuk, I.M. (2018). Pidhotovka maybutnikh fakhivtsiv medytsyny do marketynhovoyi diyal'nosti yak pedahohichna problema. Visnyk Natsional'noyi akademiyi Derzhavnoyi prykordonnoyi sluzhby Ukrayiny. Seriya: pedahohika, № 2, URL: http://nbuv.gov.ua/UJRN/Vnadped_2018_2_14 (accessed 10.05.2020). [in Ukrainian]

9. Mel'nychuk, I.M., Fedirchyk, T.D., Kalynyuk, N.M. (2019). Sutnist' osvity yak sotsial'noyi tsinnosti. Visnyk Natsional'noyi akademiyi Derzhavnoyi prykordonnoyi sluzhby Ukrayiny. Seriya: Pedahohika, 1, URL: http://nbuv.gov.ua/UJRN/Vnadped_2019_1_7.1 (accessed 10.05.2020). [in Ukrainian] 
10. Fedchyshyn, N.O. (2019). Inshomovna hramatychna kompetentnist' yak skladova pidhotovky maybutn'oho likarya u konteksti virtual'no-navchal'noho seredovyshcha. Medychna osvita, 2(82), 114-121. [in Ukrainian]

11. Khrystenko, O.M. (2015). Vykorystannya genderno zbalansovanoho materialu pid chas vykladannya istoriyi Ukrayiny. Zbirnyk naukovykh prats' Umans'koho derzhavnoho pedahohichnoho universytetu imeni Pavla Tychyny, 2, 379-387. [in Ukrainian]

12. Kalynyuk, N.M., Rohal's'kyy, I.O., Chornen'kyy, M.V. (2015). Pedahohichni (metodychni) zasady vykladannya kursu «Medychne pravoznavstvo» dlya studentiv medychnoho fakul'tetu. Medychna osvita, 4, 27-29. [in Ukrainian]

13. Shul'hay, A.H., Fedonyuk, L.Ya., Mudra, A.Ye., Oleshchuk, O.M. (2018). Mizhdystsyplinarna intehratsiya yak skladova problemno-oriyentovanoho navchannya u medychnomu universyteti. Medychna osvita, 4(80), 113-116. [in Ukrainian]

14. Kofoed, M. S. (2017). To apply or not to apply: FAFSA completion and financial aid gaps. Research in Higher Education, 58 (1), 1-39.

15. Melnychuk, I., Kalyniuk, N., Humenna, N., Rohalskyi, I., Yastremska, S., Straznikova, I., Bloshchynskyi, I. (2019). Organization of distance learning on "Nursing" specialty: methodological and legal aspects. International Journal of Applied Exercise Physiology, 8(3.1).

16. Melnychuk, I., Mozolev, O., Bloshchynskyi, I., Alieksieiev, O., Romanyshyna, L., Zdanevych, L., Prontenko, K., Prontenko, V. (2019). Influence of modern fitness technologies on the state of health and development of motorabilities of 17-19-year-old female students. Journal of Physical Education and Sport. Physical Therapy. Sports Therapy and Reabilitation and Sport, 19(3), 917-924.

17. Melnychuk, I., Svyd, I., Obod, A., Zavolodko, G., Wójcik, W., Orazalieva, S., Ziyatbekova, G. (2019). Assessment of information support quality by "friend or foe" identification systems. Przeglade lektrotechniczny, R95 NR 4, 127-131. doi:10.15199/48. 2019.04.22.

18. Mykytenko, P.V., Lapinskij, V.V. (2020). Design of medical informatics interdisciplinary integration. Information Technologies and Learning Tools, 75(1), 26-41.

19. Okamura, K. (2019) Interdisciplinarity revisited: evidence for research impact and dynamism. Palgrave Commun, 5, 141, URL: https://doi.org/10.1057/s41599-019-0352-4 (accessed 10.05.2020).

20. Renate, G.K. (2018). Interdisciplinary education: a case study. European Journal of Engineering Education,43:6, 842-859. DOI: $10.1080 / 03043797.2018 .1442417$.

21. Sergeeva, S. (2019). Monitoring of Educational Programs for the Development of Professional Competencies by Procurement Specialists in Procurement Statistics. Academic Journal of Interdisciplinary Studies, 8(2), 226-239.

22. Viktorova, L.V. (2020). Educational conditions for implementation of adults' distance Learning of Foreing Lanquages. Information Technologies and Learning Tools, 75(1), 13-25.

23. Vykhrushch, A., Melnychuk, I., Fedchyshyn, N., Pylypyshyn, O. (2019). Philosophical and Cultural Aspects of Medical Profession: Philosophical and Conceptual Peculiarities. Cultura. International Journal of Philosophy of Culture and Axiology, 16(1), 165-174.

24. Vykhrushch, A. (2017). Poezja w procesie rozwoju twórczych zdolności studentów. Kwartalnik Edukacyjny, 1(88), 56-61. [in Polish]

25. Yelahina, N., Fedchyshyn, N., Klishch, H., Horpinich, T. (2019). Effective Methods in Foreign Language Teaching of Medical Students. Медична освіта, 1(81), 48-54.

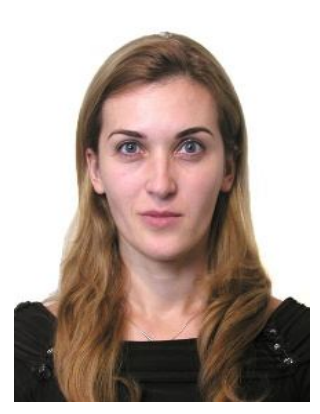

\section{Калинюк Наталя Миколаївна,}

Кандидат юридичних наук, доцент, доцент кафедри педагогіки вищої школи та суспільних дисциплін Тернопільського національного медичного університету імені І.Я. Горбачевського.

Майдан Волі, 1, м. Тернопіль, Україна, 46016.

Тел. +380976539021 .E-mail: kalunyknm@tdmu.edu.ua

Kalyniuk Natalia Mykolayvna,

PhD of Juridical Sciences, Associate Professor, Associate Professor of the Department of Pedagogy of

the Higher School and Social Science, I. Horbachevsky Ternopil National Medical University,

srt. M. Voli, 1, Ternopil, Ukraine.

Tel. +380976539021 .E-mail: kalunyknm@tdmu.edu.ua

ORCID: 0000-0002-1613-835X

Citation (APA):

Kalyniuk, N. (2020). On the question of training of future medical specialists on the basis of interdisciplinary integration. Engineering and Educational Technologies, 8 (2), 44-52. doi: https://doi.org/10.30929/2307-9770.2020.08.02.04

\section{Цитування (ДСТУ 8302:2015):}

Калинюк Н. М. До питання підготовки майбутніх медичних фрахівців на засадах міждисциплінарної інтеграції / Інженерні та освітні технології. 2020. Т. 8. № 2. С. 44-52. doi: https://doi.org/10.30929/2307-9770.2020.08.02.04

Обсяг статті: $\quad$ сторінок - 9 ; умовних друк. аркушів - 1,304. 